\title{
MOLECULAR CHARACTERIZATION OF PHOMOPSIS VEXANS ISOLATES OF EGGPLANT OF BANGLADESH
}

\author{
M M Islam', M Asaduzzaman² and M B Meah ${ }^{3}$
}

\begin{abstract}
Forty-four isolates of Phomopsis vexans were collected from eggplant producing areas of Bangladesh during the 2008-2009 growing seasons. The polymerase chain reaction (PCR) variable number of tandem repeats (VNTR) technique was used to develop molecular markers. The MR-20 primer amplified template DNA for all isolates studied and resulted in distinct bands. The banding patterns of $P$. vexans isolates were separated into five groups after results with Taq polymerase. The highest genomic DNA concentration $50 \mathrm{ng} / \mu \mathrm{l}$ was found in the isolates of 8, 14, 26, 27 and 38, and the lowest concentration of genomic DNA was found $12.5 \mathrm{ng} / \mu \mathrm{l}$ in the isolates of $1,2,5,15,17,22,30,31,33,34,36,40,41,42$ and 43 . Based on the fingerprinting the 44 isolates of Phomopsis vexans were categorized into five different groups.
\end{abstract}

Key words: Molecular characterization, Phomopsis vexans, eggplant.

\section{INTRODUCTION}

Solanum melongena L. $(2 \mathrm{n}=24)$ is also known as eggplant, aubergine, brinjal and Guinea squash. It is the only economic host of Phomopsis vexans and the disease is variously known as tip over, stem blight, canker, leaf blight or spot and fruit rot; damping off also can take place. Leaf spots (up to $3 \mathrm{~cm}$ diam.) are conspicuous, irregular in outline and may coalesce; lower leaves may be affected first. In stem lesions, the cortex dries and cracks, plants become stunted and girdling cankers cause death of the plant. Fruit spots are pale sunken, conspicuous and may affect the whole fruit; fruit may drop or remain attached, becoming mummified after a soft decay. Pycnidia are abundant. Phomopsis vexans has both $\alpha$ and $\beta$ conidia, pycnidia with short or no pycnidial beaks. It is the sole causal agent of Phomopsis fruit rot of eggplant. Eggplant suffers from 12 diseases of which fruit rot caused by Phomopsis vexans (Sacc. and Syd.) Harter is a devastating one. This pathogen remains viable for about 14 months in soil debris and in the seed from infected fruits (Kalda et al 1977). This organism is both externally and internally seed borne (Singh, 1992). The disease was first reported from Gujrat in 1914 and since then from many parts of India. Occurrence of the disease in Bangladesh has been reported by Fakir (1983) and Ahmad (1987). Crop losses range from 15-20 \% in general but 30-50 \% in severe case (Das, 1998).

There is no data in the world on the molecular characterization of Phomopsis vexans causing fruit rot. The development of molecular techniques was allowed the cataloguing of many genes involved in defense.

1. Senior Scientific Officer, BARI, Gazipur, Bangladesh

2. Executive Director, Bangladesh Science Foundation, Dhaka.

3. Professor, Plant Pathology Dept. BAU, Mymensingh, Bangladesh. 
In recent years, both mini-satellite and micro-satellite probes have been applied for DNA fingerprinting of numerous animal, plant and fungal species (reviewed by Rosewich and McDonald 1994, Weising et al. 1995). High levels of polymorphism between related genotypes were often observed and the technique found its way to diverse areas of genome analysis, including paternity testing, genotype identification and population genetics. Realizing the importance of this technology, a research program has been conducted on molecular variability of Phomopsis vexans isolates.

\section{MATERIALS AND METHODS}

Phomopsis vexans infected fruits, leaves and stems were collected from 23 eggplant producing areas in Bangladesh during the growing seasons 2008-2009. The pathogen was isolated from diseased plant parts by plating on acidified potato dextrose agar (APDA). Colonies were sub-cultured onto APDA examined for purity and kept at room temperature $\left(25 \pm 2^{0} \mathrm{C}\right.$ ).DNA finger printing of isolates of Phomopsis vexans were studied.

Cultures of 44 isolates were grown on APDA for molecular characterization of Phomopsis vexans isolates of Bangladesh. Mycelium tips of 3-5 days old purified cultures of P.vexans were transferred into $500 \mathrm{ml}$ conical flask containing $50 \mathrm{ml}$ potato dextrose (PD) broth medium and placed on electric orbital shaker for 2-3 days (continuous shaking) at $120 \mathrm{rpm}$ at $25 \pm 1^{0} \mathrm{C}$ following the procedure of Anon. (1994). Two to three days old mycelium of $P$. vexans from PD broth medium was filtered and squeezed to remove water with the help of muslin cloth. The squeezed, blotted and flattened mycelium of $P$. vexans was folded into an Al-foil paper and frozen at $-20{ }^{\circ} \mathrm{C}$ followed by drying in a freeze dryer. DNA was extracted from 44 isolates following the methods of Raeder and Broda (1985) and Anon. (2001). Dried mycelium was ground to powder with the help of a pestle and mortar. About $25 \mathrm{mg}$ powdered mycelium was poured into a $1.5 \mathrm{ml}$ centrifuge tube and suspended in $800 \mu \mathrm{l}$ of extraction buffer ( $250 \mathrm{mM} \mathrm{NaCl}, 100 \mathrm{mM}$ Tris-HCl, $100 \mathrm{mM}$ EDTA, all Sigma) by stirring on a Vortex mixer. Eighty (80) micro-liters of $10 \%$ sodium dodecyl sulphate (SDS) was added to the centrifuge tube containing the powdered mycelium and extraction buffer, mixed by inverting a few times and incubated for 30 minutes at $65^{\circ} \mathrm{C}$ in a water bath. After incubation, $352 \mu \mathrm{l}$ of $3 \mathrm{M}$ sodium acetate ( $\mathrm{pH}$ 5.2) was added into the centrifuge tube containing mycelium, extraction buffer and SDS, mixed gently and kept in ice for 15 minutes to burst the cells and denature the proteins. This mixture was centrifuged in a refrigerated centrifuge (Hawk 15/05) at $13000 \mathrm{XG}$ at $4^{0} \mathrm{C}$ for 10 minutes and the water-soluble supernatant was collected and transferred into a new centrifuge tube. Five hundred micro-liter chloroform was added to the new centrifuge tube and mixed in thoroughly on the vortex mixer. The mixture was centrifuged at $13000 \mathrm{XG}$ at $4{ }^{\circ} \mathrm{C}$ for at least 30 minutes. Chloroform precipitates the protein and long centrifugation separates long chain polysaccharides from the DNA. The upper aqueous phase (the DNA solution) was collected into clean tubes very carefully with the help of a pipette without disturbing the interface and this protein containing interface with the organic phase layer beneath the interface was discarded. Precipitation of DNA was done following the procedure of Anon. (2001). Two volumes of pure ethanol were added into the DNA solution and the mixture was kept on ice for 10 minutes to allow the DNA molecules to aggregate. The DNA was precipitated down by centrifugation at $13000 \mathrm{XG}$ at $4{ }^{0} \mathrm{C}$ for 5 minutes 
to the bottom of the centrifuge tube as a pellet. Then the supernatant was discarded with the help of a wide bore pipette and the centrifuge tube with the DNA pellet was preserved. Two hundred micro-liter of $70 \%$ ethanol was added into the centrifuge tube and stirred on a Vortex mixer for drying the DNA pellet. The tube was then centrifuged at $13000 \mathrm{XG}$ at $4^{0} \mathrm{C}$ for two minutes and the ethanol was discarded with the help of a micropipette. The DNA pellet was dried in a vacuum desiccators for two minutes and re-suspended in the required volume (depending on the size of DNA pellet) of Tris-EDTA (TE) buffer (10 mM Tris, $\mathrm{pH}$ 8.0, $1 \mathrm{M}$ EDTA, all Sigma). The solution was preserved at $-20^{\circ} \mathrm{C}$ for further experiments. The DNA was assessed following the procedure of Anon. (2001). Two micro-liters of 6X gelloading dye were mixed with $8 \mu \mathrm{l}$ of each of the genomic DNA solution in separate centrifuge tubes for each of the isolates.

For preparation of $180 \mathrm{ml}$ of a $0.8 \%$ agarose gel an amount of $1.44 \mathrm{~g}$ agarose was weighed in a conical flask and $180 \mathrm{ml}$ of $1 \mathrm{X}$ Tris-Acetate EDTA (TAE) was poured into the conical flask and the mixture was heated in a microwave oven until the agar was dissolved fully. The melted agarose gel was cooled down under the flow of tap water and poured gently in the gelcast immediately after, a comb was inserted into the gel tank for making wells. The gel was allowed at-least one hour for solidification before the comb was gently removed. The gel was submerged into the $1 \mathrm{X}$ TAE running buffers in the gel tank.Ten micro-liter of each genomic DNA sample was loaded separately into the wells of the $0.8 \%$ agarose gel, as well as $5 \mu \mathrm{l}$ standard molecular weight marker ( $\lambda$ DNA cut by HindIII + EcoR1) and run by electrophoresis at 120 millivolts for one hour for moving the negatively charged DNA towards the anode. After finishing electrophoresis, the gel was stained with $0.5 \mu \mathrm{g} / \mathrm{ml}$ ethidium bromide solution for one hour.

The stained agarose gel was rinsed with water for de-staining, illuminated by placing on an UV-trans-illuminator and photographed for assessing the DNA concentration and quality in comparison with the standard molecular weight marker. After estimating the DNA concentration, $1 \mathrm{ng} / \mu \mathrm{l}, 5 \mathrm{ng} / \mu \mathrm{l}$ and $20 \mathrm{ng} / \mu \mathrm{l}$ DNA solutions were prepared by adding the required amount of sterile distilled water (SDW). The diluted DNA solution and the original stock were stored in a refrigerator at $-20^{\circ} \mathrm{C}$ for other experiments. Two concentrations of each of $\mathrm{MgCl}_{2}$, primer and Taq polymerase enzyme was used for a series of experiments and selected concentrations were used for the rest of the study. The DNA was amplified by a polymerase chain reaction (PCR). A master-mix of $20 \mu \mathrm{l}$ was prepared. Then $19 \mu \mathrm{l}$ of this master-mix was aliquot into an $0.5 \mathrm{ml}$ PCR tube and $1 \mu \mathrm{l}$ of genomic DNA $(5 \mathrm{ng} / \mu \mathrm{l})$ was added into it. One drop of mineral oil was also added to each PCR tube. The PCR tubes were fitted into the blocks of a PCR machine (Eppendorf Mastercycler personal). The PCR machine was then run under VNTR-PCR protocol with a lid temperature $103{ }^{\circ} \mathrm{C}$.
a) $94{ }^{\circ} \mathrm{C}$ for 2 minutes
b) $94{ }^{\circ} \mathrm{C}$ for 20 seconds
c) $45{ }^{\circ} \mathrm{C}$ for 45 seconds
d) $72{ }^{\circ} \mathrm{C}$ for 2 minutes
e) Go to b and repeat b, c and d 35 times
f) $72{ }^{\circ} \mathrm{C}$ for 5 minutes and hold at $4{ }^{\circ} \mathrm{C}$

The tubes with the PCR products were taken out the PCR machine; $2 \mu \mathrm{l}$ of $6 \mathrm{X}$ loading dye were added and mixed in thoroughly. Amplified PCR products were separated on agarose. 
The MR (GAG GGT GGC GGT TCT) primer was used in the PCR.Electrophoresis of the gel and its staining and the photographing of the DNA bands were done.

\section{RESULTS AND DISCUSSION}

The lowest concentration of genomic DNA was found $12.5 \mathrm{ng} / \mu \mathrm{l}$ in the isolates of $1,2,5,15$, 17, 22, 30, 31, 33, 34, 36, 40, 41, 42 and 43 (Table 1). The lower genomic DNA concentration was found $25 \mathrm{ng} / \mu \mathrm{l}$ in the isolates of 3, 4, 6, 9, 10, 12, 13, 16, 19, 20, 21, 23, 24, 25, 28, 29, 37, 39 and 44, higher genomic DNA concentration was found 37.5 in the isolates of 7, 11, 18 and 32 and the highest $50 \mathrm{ng} / \mu \mathrm{l}$ was found in the isolates of 8, 14, 26, 27 and 38(Table 1). DNA samples of all isolates and one negative control (without DNA template) were used in the Polymerase Chain Reaction (PCR) analysis where all showed the expected banding patterns excluding negative control. The negative control (the reaction mixture without DNA) did not reveal any amplification, whereas the positive control ( $P$. vexans DNA) showed strong positive PCR product amplification. The primer MR-20 was used to detect the DNA fingerprint of 44 isolates of Phomopsis vexans. The DNA fingerprinting patterns for the isolates of $1,3,4,5,8,9,10,11,12,13,14,15,16,17,18,19$, $20,21,22,23,24,27,28,29,32,34,36,37,38,39,42,43$ and 44 were identical and so these showed that they came from closely related strains. One band missing in the sample no.6, 7 and 41 compared to the samples no.1, 3, 4, 5, 8, 9, 10, 11, 12, 13, 14, 15, 16, 17, 18, 19, 20, $21,22,23,24,27,28,29,32,34,36,37,38,39,42,43$ and 44 . In case of samples 26, 31and 40, 3 band is less visible and one band is more visible than the sample $1,3,4,5,8,9,10,11$, $12,13,14,15,16,17,18,19,20,21,22,23,24,27,28,29,32,34,36,37,38,39,42,43$ and 44. A prominent band is missing in the middle portion of the samples 2 and 25 than the samples $1,3,4,5,8,9,10,11,12,13,14,15,16,17,18,19,20,21,22,23,24,27,28,29,32$, 34, 36, 37, 38, 39, 42, 43 and 44. But samples 30, 33, and 35 have an extra prominent band in the lower portion than the samples $1,3,4,5,8,9,10,11,12,13,14,15,16,17,18,19,20$, 21, 22, 23, 24, 27, 28, 29, 32, 34, 36, 37, 38, 39, 42, 43 and 44 (Fig. 1a and 1b).

Dendogram analysis of isolates based on fingerprinting divided the isolates into five clusters. Isolates 26, 31 and 40 are in group five, isolates 2 and 25 are in group four, isolates 30, 33 and 35 are in group three, isolates 6, 7 and 41 are in group two and rest of 33 isolates are in group one (Fig. 2).

The distribution of 44 isolates of Phomopsis vexans were grouped into 5 on the basis of DNA fingerprinting have been shown in different locations (Table 2). Isolates 1, 8, 12, 21 and 35 were collected from different sites of Mymensingh district where isolates 1, 8, 12, 21 were in group one and isolates 35 in group three. Isolates 2, 5, 7 and 26 were collected from 4 locations of Jamalpur district where isolate 5 was in group one, isolate 26 in group-3, isolates 2 and 7 in group 4. From Chittagong district, isolates 3, 9, 22, 28 and 36 were collected and all of 5 isolates were in group one. Isolates 4, 6, 13, 17 and 18 were collected from 5 different rural areas of Sherpur district, among them 4,13, 17 and 18 were in group one and isolate 6 in group two. Isolates 10 and 15 were collected from two different fields of Comilla and both were in group one. Isolates 11, 16, 19, 20, 29, 32 and 40 were collected from Lalmonirhat district where isolate 40 was in group 5 and rests of isolates in group one. Isolates 14, 31 and 
39 were collected from Narayangonj district where 14 and 39 were in group one and 31 in group 5. Isolates 23 and 30 were collected from Rajshahi and 23 was in group one and 30 in group 3. Isolate 24 was collected from Bogra that was in group one. Isolates 25, 27, 33, 42 and 44 were collected from Faridpur where isolates 27, 42 and 44 were in group one and 25 was in group 4 and 33 in group 3. Isolates 34 and 38 were collected from Jessore and both were in group one. Isolate 37 was collected from Dhaka and it was in group one. Isolates 41 and 43 were collected from Rangpur where isolates 43 was in group one and isolate 41 in group two (Table 2).

DNA fingerprinting enabled us to select representative pathogen strains of $P$. vexans. This study is the first to describe this pathogen's molecular characteristics. Forty four isolates were identified, all belonging to one species but demonstrated wide molecular diversity. According to DNA fingerprinting, 44 isolates have been categorized into five groups. Piolio et al. (2003) reported that Diaporthe/Phomopsis isolates could be grouped in four major taxa: (i) Diaporthe phaseolorum var. meridionalis, (ii) Diaporthe phaseolorum var. caulivora, (iii) Diaporthe phaseolorum var. sojae and (iv) Phomopsis longicola. In addition to distinguishing interspecific and intraspecific variability, molecular markers allowed the detection of differences among the isolates within the same variety. So the present findings corroborate with the report of Piolio et al. (2003) although they did not work with $P$ vexans.

DNA removed from mycelia after chloroform extraction and ethanol precipitation and PCR inhibitors that could not be removed by repeated washing with $70 \%$ ethanol or repeated DNA replication. To reduce these contaminants, $100 \%$ ethanol was used instead of $70 \%$ ethanol to recover DNA. DNA recovered with double hellix and the target DNA sequence was consistently amplified from fungal DNA extracts. However, the fact that it was necessary to dilute this DNA for consistent amplification of the target DNA sequence indicated that some PCR inhibitors were still present. The addition of white milk to the PCR reaction allowed the consistent amplification of the target DNA fragment from undiluted DNA extracts from mycelium. The use of white milk to overcome PCR inhibitors has been previously described, although the mechanism by which this occurs is not known.

The MR-20 primer was not species specific i.e. this primer also directed the amplification of an appropriate rice pathogen Bipolaris oryzae, Erwinia anans etc. However this should not result in false positives in $P$. vexans mycelia assays because these fungi are not associated with eggplant. Alternatively, a more specific MR-20 primer could be developed. New primer can easily be incorporated into this PCR based assay, thereby providing a means for continually updating and improving the specific and sensitivity of the assay.

Table 1. Molecular behaviour of Phomopsis vexans isolates

\begin{tabular}{|l|c|c|c|c|c|c|}
\hline $\begin{array}{l}\text { Sl. } \\
\text { No. }\end{array}$ & Isolates No. & $\begin{array}{c}\text { Amount of } \\
\text { TE added }(\mu \mathrm{l})\end{array}$ & $\begin{array}{c}\text { DNA } \\
\text { concentration } \\
(\mathrm{ng} / \mu \mathrm{l})\end{array}$ & Primer & PCR & Grouping \\
\hline
\end{tabular}




\begin{tabular}{|c|c|c|c|c|c|c|}
\hline $\begin{array}{l}\text { Sl. } \\
\text { No. }\end{array}$ & Isolates No. & $\begin{array}{c}\text { Amount of } \\
\text { TE added }(\mu l)\end{array}$ & $\begin{array}{c}\text { DNA } \\
\text { concentration } \\
(\mathrm{ng} / \mu \mathrm{l})\end{array}$ & Primer & PCR & Grouping \\
\hline 1 & 1 & 130 & 12.5 & MR-20 & Positive & 01 \\
\hline 2 & 2 & 100 & 12.5 & MR-20 & Positive & 04 \\
\hline 3 & 3 & 130 & 25 & MR-20 & Positive & 01 \\
\hline 4 & 4 & 100 & 25 & MR-20 & Positive & 01 \\
\hline 5 & 5 & 200 & 12.5 & MR-20 & Positive & 01 \\
\hline 6 & 6 & 150 & 25 & MR-20 & Positive & 02 \\
\hline 7 & 7 & 100 & 37.5 & MR-20 & Positive & 02 \\
\hline 8 & 8 & 200 & 50 & MR-20 & Positive & 01 \\
\hline 9 & 9 & 100 & 25 & MR-20 & Positive & 01 \\
\hline 10 & 10 & 100 & 25 & MR-20 & Positive & 01 \\
\hline 11 & 11 & 90 & 37.5 & MR-20 & Positive & 01 \\
\hline 12 & 12 & 90 & 25 & MR-20 & Positive & 01 \\
\hline 13 & 13 & 100 & 25 & MR-20 & Positive & 01 \\
\hline 14 & 14 & 200 & 50 & MR-20 & Positive & 01 \\
\hline 15 & 15 & 100 & 12.5 & MR-20 & Positive & 01 \\
\hline 16 & 16 & 130 & 25 & MR-20 & Positive & 01 \\
\hline 17 & 17 & 90 & 12.5 & MR-20 & Positive & 01 \\
\hline 18 & 18 & 100 & 37.5 & MR-20 & Positive & 01 \\
\hline 19 & 19 & 100 & 25 & MR-20 & Positive & 01 \\
\hline 20 & 20 & 130 & 25 & MR-20 & Positive & 01 \\
\hline 21 & 21 & 100 & 25 & MR-20 & Positive & 01 \\
\hline 22 & 22 & 180 & 12.5 & MR-20 & Positive & 01 \\
\hline 23 & 23 & 100 & 25 & MR-20 & Positive & 01 \\
\hline 24 & 24 & 100 & 25 & MR-20 & Positive & 01 \\
\hline 25 & 25 & 90 & 25 & MR-20 & Positive & 04 \\
\hline 26 & 26 & 90 & 50 & MR-20 & Positive & 05 \\
\hline 27 & 27 & 200 & 50 & MR-20 & Positive & 01 \\
\hline 28 & 28 & 100 & 25 & MR-20 & Positive & 01 \\
\hline 29 & 29 & 100 & 25 & MR-20 & Positive & 01 \\
\hline 30 & 30 & 100 & 12.50 & MR-20 & Positive & 03 \\
\hline 31 & 31 & 100 & 12.50 & MR-20 & Positive & 05 \\
\hline 32 & 32 & 130 & 37.50 & MR-20 & Positive & 01 \\
\hline 33 & 33 & 120 & 12.50 & MR-20 & Positive & 03 \\
\hline 34 & 34 & 200 & 12.50 & MR-20 & Positive & 01 \\
\hline 35 & 35 & 200 & 12.5 & MR-20 & Positive & 03 \\
\hline 36 & 36 & 90 & 12.50 & MR-20 & Positive & 01 \\
\hline 37 & 37 & 100 & 25 & MR-20 & Positive & 01 \\
\hline 38 & 38 & 200 & 50 & MR-20 & Positive & 01 \\
\hline 39 & 39 & 90 & 25 & MR-20 & Positive & 01 \\
\hline 40 & 40 & 100 & 12.50 & MR-20 & Positive & 05 \\
\hline 41 & 41 & 100 & 12.50 & MR-20 & Positive & 02 \\
\hline 42 & 42 & 90 & 12.50 & MR-20 & Positive & 01 \\
\hline 43 & 43 & 200 & 12.5 & MR-20 & Positive & 01 \\
\hline 44 & 44 & 130 & 25 & MR-20 & Positive & 01 \\
\hline 45 & Negative & - & - control & MR-20 & Negative & - \\
\hline
\end{tabular}




\begin{tabular}{|l|c|c|c|c|c|c|}
\hline $\begin{array}{l}\text { Sl. } \\
\text { No. }\end{array}$ & Isolates No. & $\begin{array}{c}\text { Amount of } \\
\text { TE added }(\mu \mathrm{l})\end{array}$ & $\begin{array}{c}\text { DNA } \\
\text { concentration } \\
(\mathrm{ng} / \mu \mathrm{l})\end{array}$ & Primer & PCR & Grouping \\
\hline & control & & & & & \\
\hline
\end{tabular}

MR-20 (5’ GAGGGTGGCGGTTCT 3')
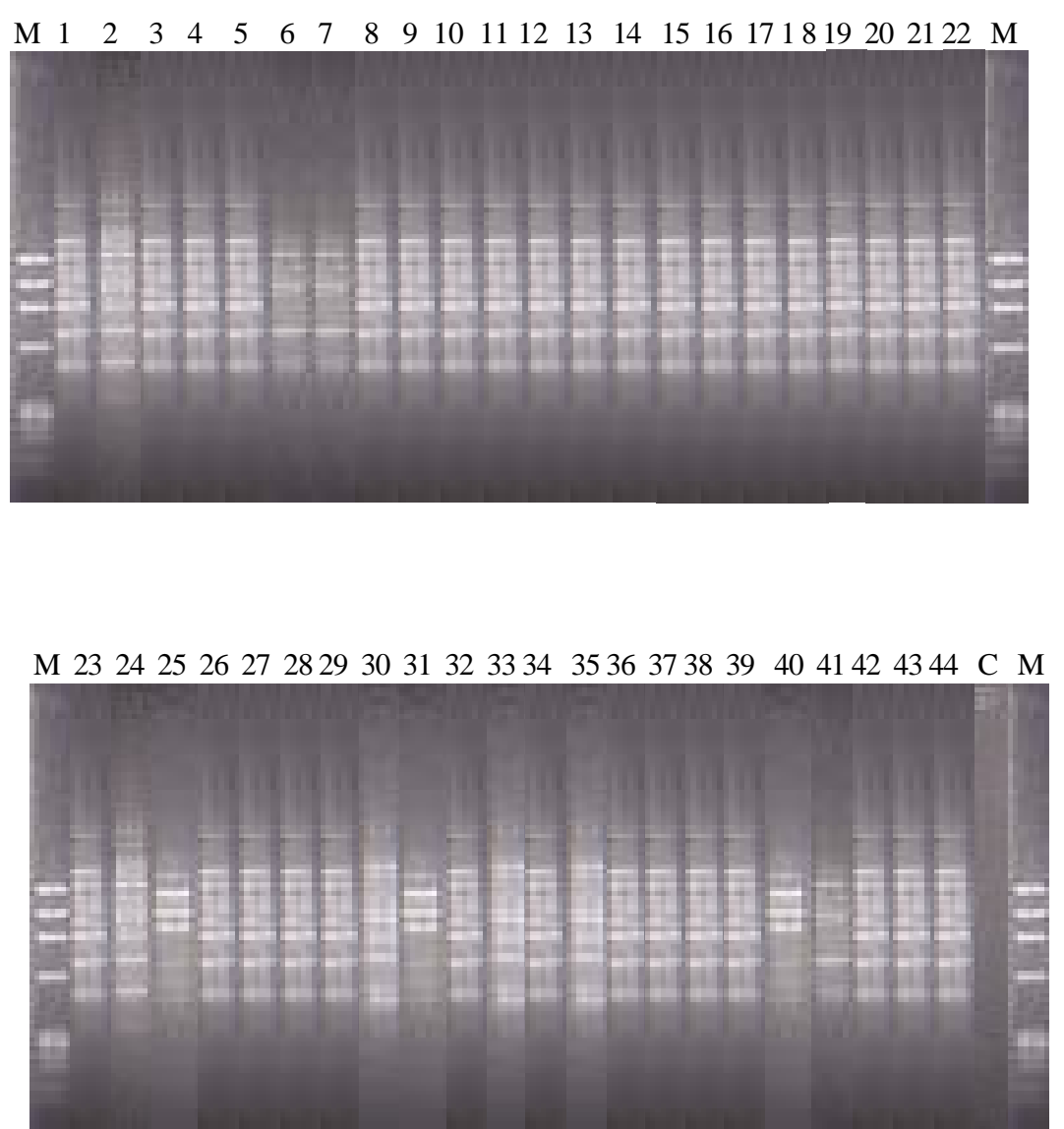

Fig.1a. PCR amplification of variable number of tandem repeats (VNTR) from 44 isolates of Phomopsis vexans using primer MR. [Lanes: M. Phi $\mathrm{x}$ 174 DNA/Hae III molecular weight markers. 1-44, isolates as numbered; C, No DNA template (negative control).
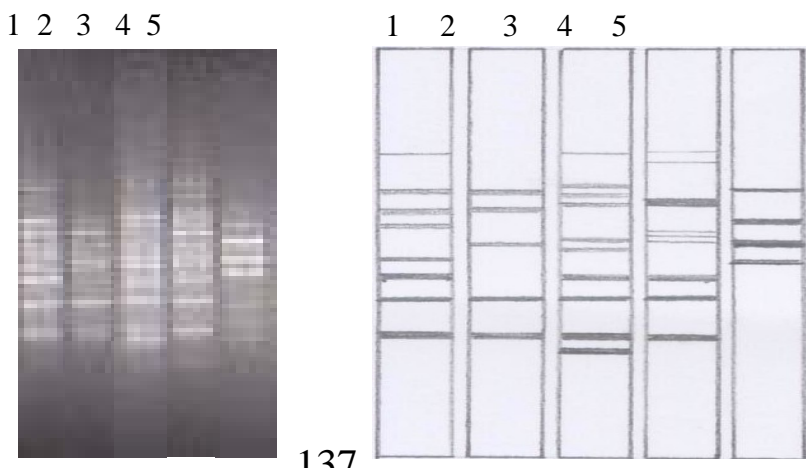

Original

Typical (Sketch) 
Fig. 1b. Five different molecular groups of Phomopsis vexans isolates.

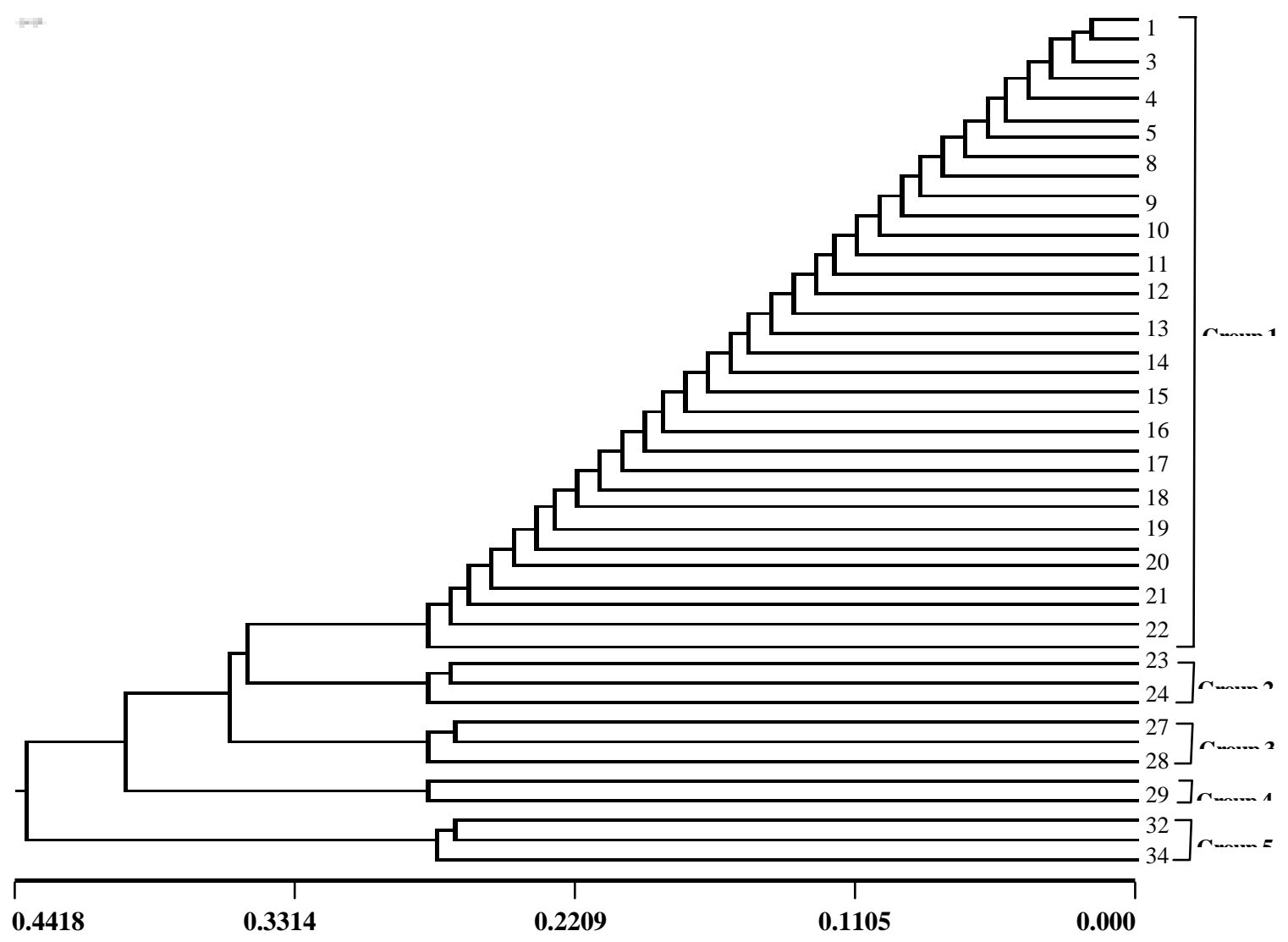

Fig. 2. Dendrogram of Phomopsis vexans isolates by VNTR assessed on agarose gel using primer MR-20 based on Nei's (1972) genetic distance. 
Table 2. Distribution of molecular groups of Phomopsis vexans isolates in different locations of Bangladesh

\begin{tabular}{|l|c|c|c|c|c|c|}
\hline \multirow{2}{*}{ Locations } & \multicolumn{5}{|c|}{ Group No } & Total \\
\cline { 2 - 6 } & Group-1 & Group-2 & Group-3 & Group-4 & Group-5 & \\
\hline Mymensingh & $1,8,12,21$ & - & 35 & - & - & 5 \\
\hline Jamalpur & 5 & - & - & 2,7 & 26 & 4 \\
\hline Chittagong & $3,9,22,28,36$ & - & - & - & - & 5 \\
\hline Sherpur & $4,13,17,18$ & 6 & - & - & - & 5 \\
\hline Comilla & 10,15 & - & - & - & - & 2 \\
\hline Lalmonirhat & $11,16,19,20,29,32$ & - & & - & 40 & 7 \\
\hline Narayangonj & 14,39 & - & - & - & 31 & 3 \\
\hline Rajshahi & 23 & - & 30 & - & - & 2 \\
\hline Bogra & 24 & - & - & - & - & 1 \\
\hline Faridpur & $27,42,44$ & - & 33 & 25 & - & 5 \\
\hline Jessore & 34,38 & - & - & - & - & 2 \\
\hline Dhaka & 37 & - & - & - & - & 1 \\
\hline Rangpur & 43 & 41 & - & - & - & 2 \\
\hline Total & 33 & 2 & 3 & 3 & 3 & 44 \\
\hline
\end{tabular}

The PCR based assay developed for the detection of $P$. vexans on infested eggplant fruit is accurate, sensitive and reliable. Because it has the 3-5 days incubation period, this test requires approximately 29 days compared to 10 days for the freezer-blotter test. Another advantage of PCR based assay is that it does not rely on visual identification of $P$. vexans on eggplant fruit, which is complicated by the frequent occurrence of morphologically similar saprobes on eggplant fruit. Thus this PCR based assay has the potential to be used for routine testing of eggplant fruits for $P$. vexans. Furthermore, this type of test may have applicability for the detection of other fungal pathogens on seed or fruit of other crops, once appropriate primer is developed.

The variability in PCR results of the 44 isolates may be due to variations in inoculum loads in the samples. In groups 1,2,3,4 and 5, the DNA extracts from P.vexans mycelia produced a distinct banding patterns whereas the negative control samples without any DNA did not produce any band. This indicated that the results were not a false positive by PCR contamination. In picture, many bands are generated as the primer anneals in 10ds of different places. Each uses the same primer and conditions but a DNA sample from different isolates. The patterns of group- 1 more or less similar that they are in the same group. In case of group 02, one band is missing compared to group 01. Three (3) bands are less visible in group three and one band is missing compared to group 01. Considering group 4, a band is not visible as like as group 01 . Group five has an extra band and one band is missing compared to the group 01 .

To distinguish interspecific and intraspecific variability of the Phomopsis vexans, molecular markers allowed the detection of differences among isolates with the different eggplant varieties. Moreover, molecular analysis was able to classify as 5 different groups or strains of 
P.vexans. Thus VNTR analysis overcame the limitation of classifying isolates based on morphological characteristics only. Fernandez and Halin (1996) using RAPD markers, were able to differentiate among taxa within the Diaporthe/Phomopsis complex, as well as among isolates within $D$. phaseolorum var. caulivora. Zhang et al. (1998) also by using PCRrestriction fragment length polymorphism, detected genomic differences among $D$. phaseolorum var. caulivora isolates and $D$. phaseolorum var. mariodionalis isolates originated from the same areas of Italy and the United States, respectively. In our study, grouping different isolates of $P$. vexans based on similarity of band patterns corresponded with grouping them based on morphological characters. Because of the congruence of both morphological and VNTR groupings and the correspondence among isolates, it was concluded that grouping assignment of the isolates was appropriate. Even when, in our study, 44 isolates were used, both morphological and molecular analysis allowed the separation of the different strains of the $P$. vexans present in the core eggplant producing areas of Bangladesh.

\section{REFERENCES}

Ahmad, Q. 1987. Sources of resistance in brinjal to Phomopsis fruit rot. Indian Phytopath.40 (1): 98.

Anonymous, 1997. Fertilizer Recommendation Guide, Bangladesh Agricultural Research Council, Farmgate, Dhaka. pp. 70-71.

Anonymous, 2001. Molecular Cloning: a laboratory manual. (Eds. Sambrook, Joseph and David W. Russel, $3^{\text {rd }}$ edition. Vol. I, II and III). Cold Spring Harbor, New York.

Das, B.H. 1998. Studies on Phomopsis fruit rot of brinjal. An M. S. thesis submitted to the Dept. of Plant Pathology, Bangladesh Agricultural University, Mymensingh. p106.

Divinagracia, G.G. 1969. Some factors affecting pycnidial production of Phomopsis vexans in culture. Philipp. Agric 53 (3-4): 173-184.

Fakir, G. A. 1983. Root and stem rot of brinjal caused by Phomopsis vexans Proceedings of $8^{\text {th }}$ Bangladesh Science Conference, Section 1. p. 67-68.

Fernandez, F.A. and Hanlin, R.T. 1996. Morphological and RAPD analysis of Diaporthe phaseolorum from soybean. Mycologia 88:425-440.

Kalda T.S., Swarup V. and Chowdhury B.1977. Resistance to Phomopsis blight in eggplant. Vegetable Science 4(2): 90-101.

Piolio, R.N., Morandi, E.N., Martinez, M.C., Lucca, F., Tozzini, A., Bisaro, V. and Hopp, H.E. 2003. Morphologic, molecular and pathogenic characterization of Diaporthe phaseolorum variability in the core soybean-producing area of Argentina. Phytopathology 33:136-146.

Rosewich, U. L. and McDonald, B. A. 1994. Meth. Mol. Biol. 5: 41-48.

Singh R.S.1992. Diseases of vegetable crops. Second Edition. Oxford and IBH Publishing Company Pvt. Ltd. New Delhi, Bombay and Calcutta. p119-121.

Weising K., Nybon h., Wolff K. and Meyer, W. 1995. DNA Fingerprinting in Plants and Fungi. CRC Press, Boca Raton, USA.

Zhang, A.W., Riccioni L., Pedersen W.L., Kollipara K.P. and Hartman, G. L. 1998. Molecular identification and phylogenetic grouping of Diaporthe phaseolorum and Phomopsis longicola isolates from soybean. Phytopathology 88 (9-12): 1306-131. 